\title{
Glutamate Transporters Regulate Lesion-Induced Plasticity in the Developing Somatosensory Cortex
}

\author{
Chihiro Takasaki, ${ }^{1,2}$ Rieko Okada, ${ }^{1}$ Akira Mitani, ${ }^{3}$ Masahiro Fukaya, ${ }^{1}$ Miwako Yamasaki, ${ }^{1}$ Yuri Fujihara, ${ }^{1,2}$ \\ Tetsuo Shirakawa, ${ }^{4}$ Kohichi Tanaka, ${ }^{5}$ and Masahiko Watanabe ${ }^{1}$ \\ ${ }^{1}$ Department of Anatomy, Hokkaido University School of Medicine, Sapporo 060-8638, Japan, ${ }^{2}$ Department of Pediatric Dentistry, Hokkaido University \\ School of Dentistry, Sapporo 060-8586, Japan, ${ }^{3}$ Cognitive Neuroscience, Human Health Sciences, Graduate School of Medicine, Kyoto University, Kyoto \\ 606-8507, Japan, ${ }^{4}$ Department of Pediatric Dentistry, Nihon University School of Dentistry, Tokyo 101-8310, Japan, and ${ }^{5}$ Laboratory of Molecular \\ Neuroscience, School of Biomedical Science and Medical Research Institute, Tokyo Medical and Dental University, Tokyo 113-8510, Japan
}

Glutamate transporters are involved in neural differentiation, neuronal survival, and synaptic transmission. In the present study, we examined glutamate transporter 1 (GLT1) expression in the neonatal somatosensory cortex of C57BL/6 mice, and pursued its role in somatosensory development by comparing barrel development between GLT1 knock-out and control mice. During the first few neonatal days, a critical period for barrels, GLT1 expression is strikingly upregulated in cortical astrocytes, whereas it was downregulated in neuronal elements to below the detection threshold. GLT1 knock-out neonates developed normally in terms of body growth, cortical histoarchitecture, barrel formation, and critical period termination. However, when row $\mathrm{C}$ whiskers were lesioned during the critical period, reduction of lesioned row $\mathrm{C}$ barrels and reciprocal expansion of intact row B/D barrels were both milder in GLT1 knock-out mice than in control littermates. Accordingly, the map plasticity index, calculated as (B + D)/2C, was significantly lowered in GLT1 knock-out mice. We also found that extracellular glutamate levels in the neonatal somatosensory cortex were significantly elevated in GLT1 knockout mice. Diminished lesion-induced plasticity was further found in mutant mice lacking glutamate-aspartate transporter (GLAST), an astrocyte-specific glutamate transporter throughout development. Therefore, glutamate transporters regulate critical period plasticity by enhancing expansion of active barrels and shrinkage of inactive barrels. Because cortical contents of glutamate receptors and GLAST were unaltered in GLT1 knock-out mice, this action appears to be mediated, at least partly, by keeping the ambient glutamate level low. Considering an essential role of glutamate receptors in the formation of whisker-related thalamocortical synapse patterning, glutamate transporters thus facilitate their activity-dependent remodeling.

Key words: glutamate transporter; barrel; somatosensory; development; critical period; plasticity; mouse

\section{Introduction}

Whiskers are tactile hairs on the face of nonhuman mammals (Munger and Ide, 1988) and are topographically represented as modular patterns at somatosensory stations of rodents (Woolsey and Van der Loos, 1970). Whisker-related patterns are referred to as barrels in the somatosensory cortex, barreloids in the thalamus, and barrelettes in the brainstem. The development of these patterns is altered by peripheral lesions during early neonatal days known as the critical, or sensitive, period, and then consolidated as permanent structures. If sensory nerves innervating whisker follicles are completely severed during the critical period, the central patterns are blurred or fused (Weller and Johnson, 1975; Belford and Killackey, 1980; Chiaia et al., 1992; Yamakado,

Received Nov. 21, 2007; revised March 30, 2008; accepted April 8, 2008.

This work was supported by Special Coordination Funds for promoting Science and Technology, Grants-in-Aid for Scientific Research (S) (19100005) (M.W.), and Grants-in-Aid for Scientific Research on Priority Area (17023001) (M.W.) provided by the Ministry of Education, Culture, Sports, Science, and Technology of Japan. M.W. was also supported in part by the Uehara Foundation, Naito Foundation, and Akiyama Foundation.

Correspondence should be addressed to Masahiko Watanabe, Department of Anatomy, Hokkaido University School of Medicine, Sapporo 060-8638, Japan. E-mail: watamasa@med.hokudai.ac.jp.

DOI:10.1523/JNEUROSCI.0861-08.2008

Copyright $\odot 2008$ Society for Neuroscience $\quad$ 0270-6474/08/284995-12\$15.00/0
1995; Toki et al., 1999). When particular whiskers are lesioned during the critical period, lesioned barrels shrink in the somatosensory cortex and adjacent intact barrels expand reciprocally; this process is termed lesion-induced plasticity (Van der Loos and Woolsey, 1973; Killackey et al., 1976; Woolsey and Wann, 1976; Jeanmonod et al., 1977). Through this activity-dependent process, crude sensory maps are refined and remodeled into functional ones that match with the peripheral receptor surface in a point-to-point manner. Analyses of gene-engineered mice have addressed that glutamatergic signalings through the NMDA-type receptor and metabotropic glutamate receptor 5 (mGluR5) play an essential role in the formation of whisker-related central patterns (Li et al., 1994; Fox et al., 1996; Kutsuwada et al., 1996; Iwasato et al., 1997, 2000; Hannan et al., 2001).

Extracellular glutamate concentration has to be kept low enough to terminate glutamate receptor activation and to protect neurons from excitotoxicity by means of high-affinity glutamate transporters on the cell membrane (Hertz, 1979; Choi, 1992). Glutamate transporter 1 (GLT1) and glutamate-aspartate transporter (GLAST) are the predominant astrocytic glutamate transporters with relative abundance in the telencephalon or cerebellum, respectively, of adult animals (Danbolt, 2001). Subse- 
quently, GLT1 has been shown to be expressed in neuronal elements transiently during embryonic stages (Furuta et al., 1997; Yamada et al., 1998; Northington et al., 1999), although a particular splice form of GLT1 was reported to be expressed in adult brains (Chen et al., 2002, 2004; Schmitt et al., 2002; Berger et al., 2005). Previous reports have demonstrated physiological roles of these transporters in neuronal differentiation and survival, synaptic transmission and plasticity, and metabolic cross talk between neurons and glia (Tanaka et al., 1997; Watase et al., 1998; Katagiri et al., 2001; Voutsinos-Porche et al., 2003; Takayasu et al., 2005, 2006; Matsugami et al., 2006). Little is known, however, about their role in activity-dependent synapse development, through which cortical circuits attain functional and anatomical maturity (O'Leary et al., 1994; Singer, 1995; Crair, 1999).

In the present study, we investigated the role of glutamate transporters in barrel development. We found that barrel formation and critical period termination occurred normally in the somatosensory cortex of GLT1 knock-out (KO) mice, but their lesion-induced plasticity was significantly diminished compared with control littermates. Reduced plasticity was also observed in GLAST-KO mice. These findings suggest that glutamate transporters facilitate activity-dependent remodeling of somatosensory maps during the critical period.

\section{Materials and Methods}

Animals. Mouse pups were obtained from breeding pairs of C57BL/6J wild-type mice for expression analysis, and from pairs of heterozygous GLT1 (Tanaka et al., 1997), GLAST (Watase et al., 1998), and mGluR5 (stock 003558; The Jackson Laboratory, Bar Harbor, ME) mutant mice for barrel analyses. Mice were treated according to the guidelines for the care and use of laboratory animals of the Hokkaido University School of Medicine and Kyoto University. The day after overnight mating was counted as embryonic day 0 (E0), and only pups born on the 19th day of gestation were used. The day of birth $(\sim 24 \mathrm{~h})$ was designated as postnatal day 0 (P0). Genotyping of genomic tail DNA by PCR and phenotypic analyses on barrel development were performed in a blind manner. Under deep pentobarbital anesthesia (100 $\mathrm{mg} / \mathrm{kg}$ of body weight, i.p.), mice were fixed by transcardial perfusion with $4 \%$ paraformaldehyde $/ 0.1 \%$ picric acid in $0.1 \mathrm{~m}$ sodium phosphate buffer (PB), pH 7.2. Sections for histochemical and immunohistochemical analyses were prepared using a microslicer (40 $\mu \mathrm{m}$ thick) or cryostat $(30 \mu \mathrm{m})$.

Antibody. We used rabbit GLT1 antibody $(1 \mu \mathrm{g} / \mathrm{ml}$; GLT1/1 raised against 500-525 aa) (Yamada et al., 1998), guinea pig GLAST antibody (1 $\mu \mathrm{g} / \mathrm{ml}$ ) (Shibata et al., 1997), mouse microtubule-associated protein-2 (MAP2) antibody (4 $\mu \mathrm{g} / \mathrm{ml}$; no. 1284959; Roche Diagnostics, Mannheim, Germany), mouse neurofilament 160 antibody (1:100; N5264; Sigma-Aldrich, St. Louis, MO), guinea pig type 2 vesicular glutamate transporter (VGluT2) antibody $(1 \mu \mathrm{g} / \mathrm{ml})$ (Miyazaki et al., 2003), and guinea pig or rabbit mGluR5 antibody $(1 \mu \mathrm{g} / \mathrm{ml})$ (Uchigashima et al., 2007). To detect AMPA-type glutamate receptors, a mixture of rabbit GluR1 and GluR2 antibodies ( $1 \mu \mathrm{g} / \mathrm{ml}$ each) was used (Shimuta et al., 2001).

Immunohistochemistry. All incubations were performed at room temperature. After overnight incubation with the primary antibody, sections were incubated with fluorescein isothiocyanate (FITC)- or indocarbocyanine (Cy3)-conjugated species-specific secondary antibodies for $2 \mathrm{~h}$ (Jackson ImmunoResearch, West Grove, PA). Stained sections were photographed using a confocal laser-scanning microscope (FV1000; Olympus Optical, Tokyo, Japan). For preembedding silver-enhanced immunogold staining, microslicer sections were dipped in 5\% bovine serum albumin (BSA)/0.02\% saponin/PBS for $30 \mathrm{~min}$ and incubated overnight with GLAST or mGluR5 antibody diluted with $1 \%$ BSA/0.004\% saponin/PBS followed by anti-rabbit IgG linked to $1.4 \mathrm{~nm}$ gold particles (Nanogold; Nanoprobes, Stony Brook, NY) for $2 \mathrm{~h}$. Immunogold staining was intensified with a silver enhancement kit (HQ silver; Nanoprobes). Then, sections were treated with $2 \%$ osmium tetroxide for
$30 \mathrm{~min}$, stained in blocks with $2 \%$ uranyl acetate for $30 \mathrm{~min}$, dehydrated, and embedded in Epon 812.

Immunoblot. Homogenates of P2 cerebral cortex $(n=3$ each for GLT1-KO and control mice) were prepared by sonication in ice-cold buffer containing $10 \mathrm{~mm}$ Tris- $\mathrm{HCl}$, pH 7.0, $20 \mathrm{~mm} \mathrm{KCl,} 1$ mM EDTA, 1 mM EGTA, and $0.25 \mathrm{~m}$ sucrose. Protein concentration was determined by the Lowry's method. Protein samples $(40 \mu \mathrm{g})$ were separated by $7.5 \%$ SDS-PAGE under reduced conditions, and electroblotted onto a nitrocellulose membrane (Whatman, Dassel, Germany). The membrane was immunoreacted with the following primary antibodies for $2 \mathrm{~h}$ : GLT1 antibody, GLAST antibody, mGluR5 antibody, and a mixture of GluR1 and GluR2 antibodies ( $1 \mu \mathrm{g} / \mathrm{ml}$ for each). Immunoreactions were visualized using the ECL detection system (GE Healthcare, Little Chalfont, Buckinghamshire, UK). For semiquantification, gray levels of protein bands on films were measured using IPLab software (Nippon Roper, Tokyo, Japan), and $\beta$-actin was used as an internal standard for comparison. Student's $t$ test was used for statistical comparisons.

Barrel analyses. Barrels were visualized by cytochrome oxidase (CO) histochemistry (Wong-Riley, 1979). The right infraorbital nerve (ION) was transected to determine when the critical period terminated. Under hypothermia-induced anesthesia, a vertical slit was made just behind the mystacial pad to expose the right ION. The ION was cut with a pair of iridectomy scissors, the cut edge was subjected to electrical cautery to prevent nerve regeneration, and then pups were returned to their mothers. After $8 \mathrm{~d}$, mice were anesthetized by pentobarbital $(100 \mathrm{mg} / \mathrm{kg}$ of body weight) and killed for CO histochemistry. Optical density was measured along two crossing lines through C1, C2, and C3 barrels and through B2, C2, and D2 barrels. Developmental appearance and critical period termination were judged only when all these barrels were visibly segregated and the summed relative density for each measured barrel exceeded 20,000 arbitrary units (supplemental Fig. S1, available at www.jneurosci.org as supplemental material). To compare genotypic differences, we estimated the age when barrels appeared in 50\% of mice $\left(\mathrm{DA}_{50}\right)$ and the age when the critical period was terminated in $50 \%$ of mice $\left(\mathrm{CPT}_{50}\right)$. To obtain the optimal $\mathrm{DA}_{50}$ and $\mathrm{CPT}_{50}$ values and their 95\% confidence intervals, probit regression analysis was used (Finney, 1971); the fraction of mice that had formed barrels or completed the critical period was converted into probits at each postnatal age. Probitfitted linear regression lines were used for calculation. Differences between control and mutant $\mathrm{DA}_{50}$ or $\mathrm{CPT}_{50}$ values were considered statistically significant, if there was no overlap between their confidence intervals. Fisher's exact probability test was used for statistical evaluation. To compare the size of barrels, the area of $\mathrm{C} 2 / \mathrm{C} 3$ barrels was also measured.

Row $\mathrm{C}$ whiskers were lesioned to compare critical period plasticity. Hair follicles of the right row $\mathrm{C}$ whiskers were cauterized at P0, P2, or P4, and CO histochemistry and immunofluorescence were performed on P15. Whisker pads were examined stereoscopically and histologically to verify the absence of regrowth. Area measurements were performed with IPLab software (Nippon Roper) for a pair of barrels in each row (A2/A3, $\mathrm{B} 2 / \mathrm{B} 3, \mathrm{C} 2 / \mathrm{C} 3, \mathrm{D} 2 / \mathrm{D} 3$, or E2/E3) including their intervening septa. In measurement of fused, lesioned row $\mathrm{C}$ barrels, the extent of $\mathrm{C} 2 / \mathrm{C} 3$ barrels was defined by the location of adjacent B2/B3 and D2/D3 barrels. From the scores, we calculated the ratio of row $\mathrm{C}$ or row $\mathrm{B} / \mathrm{D}$ to the total measured area and the map plasticity index (MPI). Statistical differences were measured with the Mann-Whitney $U$ test.

Patterning of cortical neurons and thalamocortical afferent terminals was examined by Nissl staining with NeuroTrace 500/525 green fluorescent Nissl stain (Invitrogen, Carlsbad, CA) and VGluT2 immunofluorescence, respectively.

Brain microdialysis. P3 GLT1 mice were anesthetized with a mixture of $1.0 \%$ halothane and nitrous oxide/oxygen (7:3). The head of the animal was held with surgical tape in a stereotaxic apparatus (type 1430; David Kopf, Tujunga, CA). Burholes for probe insertion were made and the dura was carefully incised.

A thermocouple needle-probe of $0.4 \mathrm{~mm}$ diameter (TN-800S; Unique Medical, Tokyo, Japan) and a thermocouple meter (TME-300; Unique Medical) were used to monitor brain temperature. The thermocouple probe was inserted in the right cortex $(1.8-2.2 \mathrm{~mm}$ rostral to the $\lambda$, 
$1.3-1.7 \mathrm{~mm}$ lateral to the midline, at a depth of $1.0 \mathrm{~mm}$ from the cortical surface) at an angle of $15^{\circ}$ rostral to the vertical plane. An identical thermocouple needle probe and thermocouple meter assembly was used to monitor the body temperature. A small incision was made in the abdominal skin to position the probe in the subcutaneous space of the abdomen. The body and brain temperatures were maintained at 36$37^{\circ} \mathrm{C}$ with a heating lamp (Koehler type illumination lamp; Olympus, Tokyo, Japan). A microdialysis probe (0.5-mm-long dialysis membrane; $0.22 \mathrm{~mm}$ diameter; molecular weight cutoff, 50,000; A-I-4-005; Eicom, Kyoto, Japan) perfused with Ringer's solution at a flow rate of $0.8 \mu \mathrm{l} / \mathrm{min}$ by a microinfusion pump (ESP-32; Eicom) was inserted perpendicularly into the left somatosensory cortex $(0.8-1.2 \mathrm{~mm}$ rostral to $\lambda, 1.3-1.7 \mathrm{~mm}$ lateral to the midline, $0.6-0.8 \mathrm{~mm}$ ventral to the cortical surface). Samples (every $5 \mathrm{~min} ; 4.0 \mu \mathrm{l}$ ) of the dialysate were collected consecutively. In each mouse, two samples were collected before insertion of the microdialysis probe, and 12 samples were collected after insertion.

After collection of dialysate samples, the animals were killed by an overdose of pentobarbital, and the brains were removed. The position of the microdialysis probe in the somatosensory cortex was examined histologically, and tails were collected for genotyping in a blind manner.

Glutamate assay. The enzymatic cycling procedure for the glutamate assay was performed essentially as described previously (Mitani and Tanaka, 2003). In brief, the dialysate $(4.0 \mu \mathrm{l})$ was reacted first to form $\mathrm{NADH}$ with $20.0 \mu \mathrm{l}$ of enzymatic reagent containing $0.1 \mathrm{M}$ hydrazine buffer, pH 9.0 (Wako, Osaka, Japan), $0.4 \mathrm{~mm} \mathrm{NAD}^{+}$(Sigma-Aldrich), $0.3 \mathrm{~mm}$ ADP (Sigma-Aldrich), and $20 \mu \mathrm{g} / \mathrm{ml}$ beef liver glutamate dehydrogenase (EC 1.4.1.3; Roche Diagnostics). The mixture was incubated at $37^{\circ} \mathrm{C}$ for $30 \mathrm{~min}$, and the reaction was stopped by the addition of $5.0 \mu \mathrm{l}$ of $1 \mathrm{M} \mathrm{NaOH}$ followed by heating to $60^{\circ} \mathrm{C}$ for $20 \mathrm{~min}$. Subsequently, for triplicate determinations, three $5 \mu$ l aliquots were transferred into fluorometer tubes and used for $\mathrm{NAD}^{+}-\mathrm{NADH}$ cycling (Kato et al., 1973). The second reagent $(50 \mu \mathrm{l})$ was added to the tubes. The reagent contained $0.1 \mathrm{~m}$ Tris-HCl buffer, $\mathrm{pH}$ 8.0, (Wako), 0.02\% 2-mercaptoethanol (Wako), $0.02 \%$ bovine serum albumin (Sigma-Aldrich), 1.8\% ethanol (Wako), $12 \mathrm{~mm}$ oxaloacetic acid (Wako), $50 \mu \mathrm{g} / \mathrm{ml}$ alcohol dehydrogenase (EC 1.1.1.1; Roche Diagnostics), and $2.5 \mu \mathrm{g} / \mathrm{ml}$ malate dehydrogenase (EC 1.1.1.37; Roche Diagnostics). The tubes were incubated at $37^{\circ} \mathrm{C}$ for $60 \mathrm{~min}$, and then heated at $100^{\circ} \mathrm{C}$ for $5 \mathrm{~min}$ to stop the reaction. For the indicator reaction, $1.0 \mathrm{ml}$ of the third reagent, which contained $0.5 \mathrm{M}$ hydrazine buffer, $\mathrm{pH} 9.0,0.2 \mathrm{mM} \mathrm{NAD}^{+}$, and $2 \mu \mathrm{g} / \mathrm{ml}$ malate dehydrogenase, was added to the fluorometer tubes. The tubes were incubated at $26^{\circ} \mathrm{C}$ for $30 \mathrm{~min}$, and NADH fluorescence was measured with a fluorometer (F-2500; Hitachi, Tokyo, Japan). Glutamate standards were quantified in parallel with samples from each experiment, and glutamate concentrations were read from the standard curve. The sensitivity was $0.05-$ $0.1 \mathrm{pmol} / \mu \mathrm{l}$.

ANOVA followed by Scheffé's post hoc test was used to measure statistical differences in glutamate levels. Data are presented as the mean \pm SEM. Statistical differences were considered significant for $p<0.05$.

\section{Results}

\section{GLT1 is upregulated in cortical astrocytes during early neonatal days}

Using GLT1 antibody raised against the sequence common to all known splice variants (Rauen et al., 2004), we first examined temporal profile of GLT1 expression in the neonatal somatosensory cortex of C57BL/6 mice. The specificity of GLT1 antibody and immunohistochemistry was verified by blank immunohistochemical and immunoblot labeling in GLT1-KO brains (Fig. $1 A, D)$ and with use of GLT1 antibody preabsorbed with the antigen (Fig. $1 B, C$ ).

Because the lamina IV of the somatosensory cortex comes into existence at P3 (Agmon et al., 1993), we examined the cortical plate overlying the lamina $\mathrm{V}$ at $\mathrm{P} 0$ (Fig. $2 A-F$ ) and P2 (Fig. $2 G-$ $L$ ), and the lamina IV at P3 (Fig. $2 M-R$ ) and P4 (Fig. $2 S-W$ ), using Nissl-stained adjacent sections as references for cortical layers (Fig. 2A, G,M). At P0, GLT1 staining was most intense in

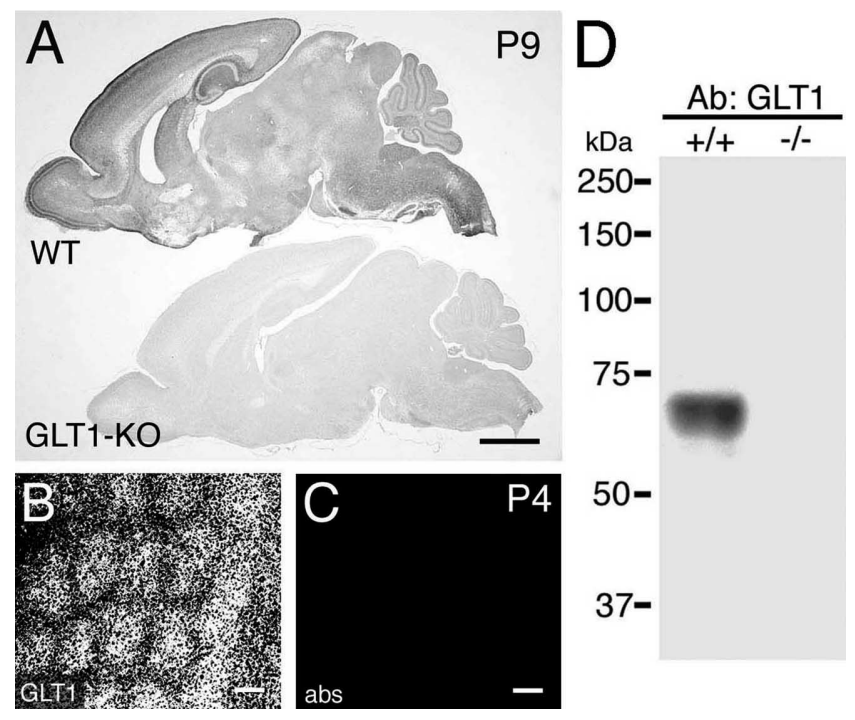

Figure 1. Specificity of GLT1 immunohistochemistry in developing mouse brains. $\boldsymbol{A}$, Immunoperoxidase staining of paraffin sections from P9 mice. The absence of staining in the GLT1-KO brain section (bottom) indicates the specificity of immunostaining in the control brain section (top). $\boldsymbol{B}, \boldsymbol{C}$, Immunofluorescence in the P4 somatosensory cortex with use of GLT1 antibody in the absence $(\boldsymbol{B})$ or presence $(\boldsymbol{C}$; i.e., absorbed GLT1 antibody) of antigen peptide. $\boldsymbol{D}, \mathrm{GLT1}$ immunoblot of brain extracts from control $(+/+)$ and GLT1-KO $(-/-)$ mice. Scale bars: $A, 1$ $\mathrm{mm} ; \boldsymbol{B}, \boldsymbol{C}, 100 \mu \mathrm{m}$.

the early-differentiating lamina VI and least intense in the latedifferentiating cortical plate (Fig. $2 A, B$ ). Within the cortical plate, GLT1 was detected in various neuronal elements, including neurofilament-positive axons (Fig. 2C), VGluT2-positive glutamatergic terminals (Fig. 2D), and MAP2-positive dendrites (Fig. $2 E$ ), whereas it overlapped only partially in GLAST-positive glial elements (Fig. $2 F$ ). The overlap of GLT1 with GLAST increased substantially at P2 (Fig. $2 \mathrm{~L}$ ) and became almost complete at P3 (Fig. $2 R$ ). Simultaneously, GLT1 became undetectable in axons and terminals by P2 (Fig. $2 I-K$ ), and dendrites by P3 (Fig. 2Q). At P4, GLT1 displayed remarkable upregulation in GLASTpositive glial elements (Fig. $2 T-W$ ), displaying barrel-like appearance by GLT1 immunofluorescence (Fig. 2S). In the neonatal period from P0 to P4, GLT1 is thus downregulated in neuronal elements to below the detection threshold, and is strikingly upregulated in cortical astrocytes.

Interestingly, the accomplishment of GLT1 switching at around P3 appears to corresponds to the stages for whiskerrelated patterning of thalamocortical afferents (i.e., barrel formation) (Senft and Woolsey, 1991; Rebsam et al., 2002) and for loss of lesion-induced plasticity (Van der Loos and Woolsey, 1973; Woolsey and Wann, 1976; Jeanmonod et al., 1977, 1981), although the two developmental events are not causally linked (Rebsam et al., 2005).

\section{Role of GLT1 in barrel development}

The role of GLT1 in somatosensory development was pursued in the somatosensory cortex by comparing the stage of barrel appearance (formation), the stage of critical period termination, and the magnitude of lesion-induced plasticity in GLT1-KO and control littermates. Body weight (in grams) did not differ significantly between GLT1-KO and control littermates at P0 [1.4 \pm $0.2(n=19)$ vs $1.5 \pm 0.2(n=9)], \mathrm{P} 4[3.2 \pm 0.1(n=7)$ vs $3.2 \pm$ $0.4(n=6)]$, and P15 [7.0 $\pm 0.9(n=21)$ vs $7.0 \pm 1.1(n=13)]$ (mean $\pm \mathrm{SD} ; p>0.05$ for each time point, Student's $t$ test), 

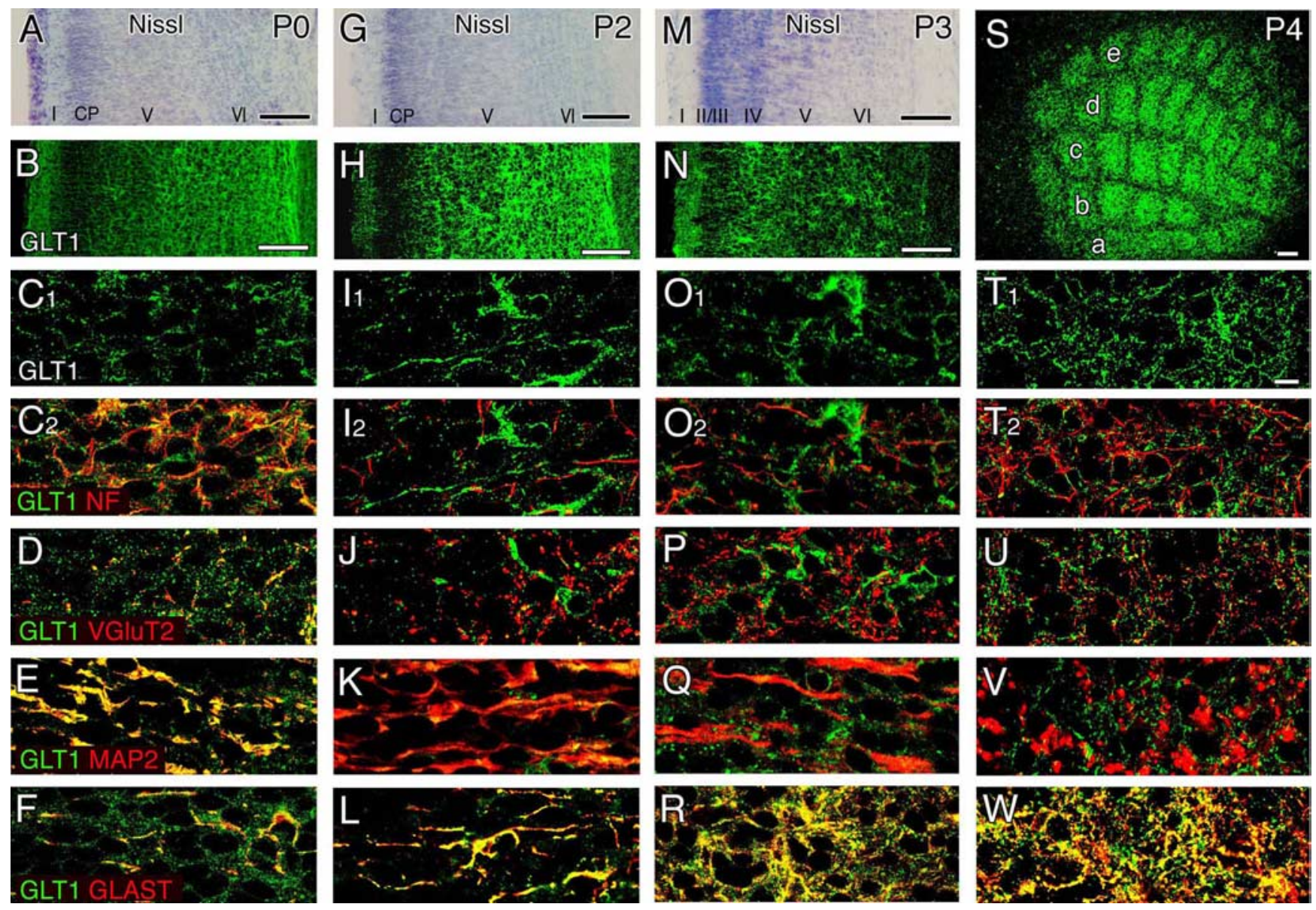

Figure 2. Neuron-to-astrocyte switching of GLT1 expression accomplishes by $\mathrm{P} 3$ in the somatosensory cortex. P0 (A-F), P2 (G-L), P3 $(M-R), P 4(S-W) . A, B, G, H, M, N, S, L$ Lw-power images of the somatosensory cortex. $\boldsymbol{A}, \boldsymbol{G}$, and $\boldsymbol{M}$ are Nissl-stained images of coronal sections used as a reference of cortical layers I through VI. CP indicates the cortical plate. $\boldsymbol{B}, \boldsymbol{H}$, and $\boldsymbol{N}$ are adjacent coronal sections stained for GLT1. $S$ is a flattened horizontal section through the layer IV of the somatosensory cortex. GLT1 expression disappears from neurofilament-positive axons by P2 and from MAP2-positive dendrites by $P 3$, whereas that in GLAST-positive astrocytes augments reciprocally from P0 to $P 4$. Note barrel-like patterning by GLT1 immunofluorescence at $P 4$. Letters a $-\mathrm{e}$ indicate five rows of cortical barrels. $(-F, I-L, 0-R, T-W$, High-power images of double immunofluorescence for GLT1 and neurofilament-160 $(\boldsymbol{C}, I, \boldsymbol{O}, \boldsymbol{T}), \mathrm{VGluT2}(\boldsymbol{D}, \boldsymbol{J}, \boldsymbol{P}, \boldsymbol{U}), \mathrm{MAP2}(\boldsymbol{E}, \boldsymbol{K}, \mathbf{Q}, \boldsymbol{V})$, or GLAST $(F, L, R, W)$. Scale bars: $A, B, G, H, M, N, S, 100 \mu \mathrm{m}$; (in $\left.T_{1}\right) C-F, I-L, 0-R, T-W, 10 \mu \mathrm{m}$.

indicating that GLT1-KO mice grew normally until P15. This is consistent with our previous report (Tanaka et al., 1997).

\section{Barrel appearance}

CO histochemistry was performed at P2-P5 (Fig. 3A-H). Five rows of large barrels in the posterior barrel subfield, which correspond to long mystacial whiskers on the snout, were invisible, obscure, or not fully segregated at P2 and P3 in any GLT1-KO or control mice. By using densitometric measurement for the judgment of barrel appearance (supplemental Fig. S1, available at www.jneurosci.org as supplemental material), we confirmed that barrels appeared in none of GLT1-KO and control mice at P2 and P3 (see Fig. 6A). The percentage of mice judged to form barrels increased to 64 and 75\% in GLT1-KO and control mice, respectively, at P4, and reached $100 \%$ in both genotypes at P5. Using these scores, a probit regression analysis was used to calculate the age at which barrels appeared in $50 \%$ of mice $\left(\mathrm{DA}_{50}\right) . \mathrm{DA}_{50}$ values were P3.8 (95\% confidence interval, P3.1-P4.4) in GLT1-KO mice and P3.8 (P3.3-P4.1) in control mice, showing no significant difference (Fisher's exact probability test, $p>0.05$ ).

The size of barrels was compared by measuring the area of C2-C3 barrels in mice judged to form barrels. The percentage of summed C2-C3 area was $103.1 \pm 18.4 \%$ in GLT1-KO mice $(n=$ 7 ; mean \pm SD) vs $100.0 \pm 16.8 \%$ in control mice $(n=6 ; p>0.05$, $t$ test $)$ at $\mathrm{P} 4$, and $113.8 \pm 14.6 \%$ in GLT1-KO mice $(n=5)$ versus $100.0 \pm 6.6 \%$ in control mice $(n=68 ; p>0.05)$ at $\mathrm{P} 5$, showing comparable barrel development in GLT1-KO mice.

\section{Critical period termination}

After transection of the right ION, lesioned (contralateral) and intact (ipsilateral) cortices were examined by CO histochemistry $8 \mathrm{~d}$ later (Fig. $4 A-H$ ). CO intensity was diminished in lesioned barrels, and barrels were blurred and fused into continuous rows in all GLT1-KO and control mice lesioned on P2 (Fig. $4 A_{1}, B_{1}$ ): the critical period was thus not terminated in these mice at P2 (see Fig. $6 B$ ). Separation into individual barrels was still incomplete in the majority of GLT1-KO and control mice lesioned on P3 (Fig. $\left.4 C_{1}, D_{1}\right)$ : the percentage of mice that had completed the critical period was 30 and $25 \%$, respectively. The percentage increased to 93 and 92\% in P4-lesioned GLT1-KO and control mice, respectively (Fig. $4 E_{1}, F_{1}$ ), and was $100 \%$ in both genotypes lesioned on P5 (Figs. $4 G_{1}, H_{1}, 6 B$ ). The age at which the critical period was terminated in $50 \%$ of mice $\left(\mathrm{CPT}_{50}\right)$ was calculated to be P3.2 (95\% confidence interval, P2.8-P3.5) in GLT1-KO mice and P3.3 (P2.9-P3.7) in control mice, showing no significant difference $(p>0.05)$. No apparent changes were observed in the intact cortex (Fig. $4 \mathrm{~A}_{2}-\mathrm{H}_{2}$ ). 


\section{Developmental Appearance}

GLT1-KO
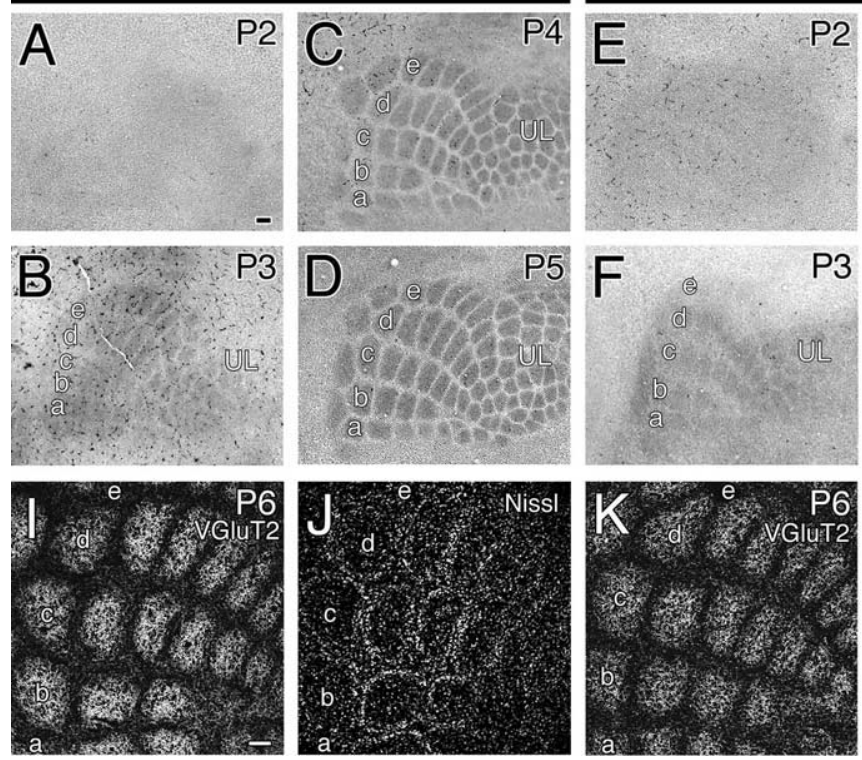

control

P2
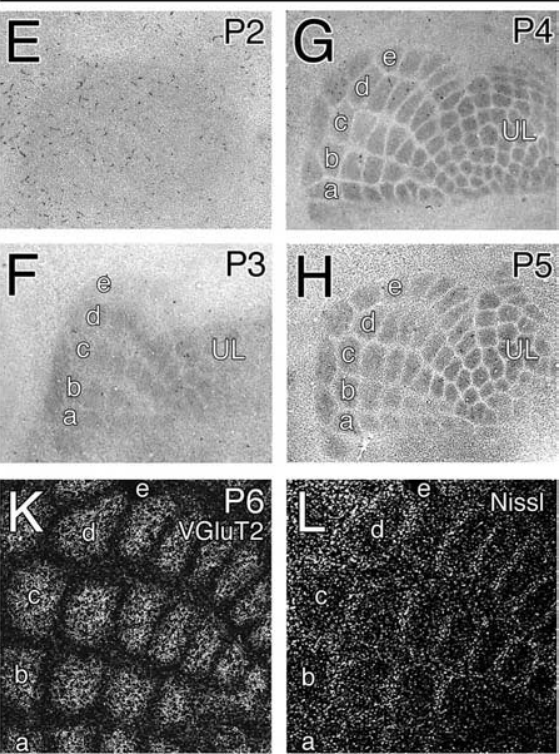

Figure 3. Normal developmental appearance of cortical barrels in GLT1-K0 neonates. GLT1-KO $(\boldsymbol{A}-\boldsymbol{D}, \boldsymbol{I}, \boldsymbol{J})$ and control $(\boldsymbol{E}-\boldsymbol{H}$, $\boldsymbol{K}, \boldsymbol{L})$ mice at $\mathrm{P} 2(\boldsymbol{A}, \boldsymbol{E}), \mathrm{P} 3(\boldsymbol{B}, \boldsymbol{F}), \mathrm{P} 4(\boldsymbol{C}, \boldsymbol{G}), \mathrm{P} 5(\boldsymbol{D}, \boldsymbol{H})$, and $\mathrm{P} 6(\boldsymbol{I}-\boldsymbol{L}) . \boldsymbol{A}-\boldsymbol{H}$, Cytochrome oxidase histochemistry. $\boldsymbol{I}, \boldsymbol{K}$, Thalamocortical terminal labeling by VGluT2 immunofluorescence. J, $L$, Neuronal labeling by Nissl staining. UL indicates barrels corresponding to short whiskers on the upper lip. Letters a-e indicate five rows of cortical barrels. Scale bars, $100 \mu \mathrm{m}$.

\section{Lesion-induced plasticity}

To examine lesion-induced plasticity during the critical period, hair follicles of right row $\mathrm{C}$ whiskers were electrocauterized at $\mathrm{P} 0$, $\mathrm{P} 2$, and $\mathrm{P} 4$. Changes in barrel map structure were examined by $\mathrm{CO}$ histochemistry at P15 (Fig. 5A-F). When row $\mathrm{C}$ hair follicles were lesioned on $\mathrm{P} 0$ and $\mathrm{P} 2$, row $\mathrm{C}$ barrels in the lesioned cortex were diminished in size and fused into a continuous row, whereas adjacent row $\mathrm{B}$ and row $\mathrm{D}$ barrels expanded reciprocally in both GLT1-KO and control mice (Fig. 5A-D). However, the extents of reduction in lesioned barrels and reciprocal expansion in intact barrels were both milder in GLT1-KO mice than in control mice (Fig. 5, compare $A_{1}, B_{1}$, and $C_{1}, D_{1}$ ). No such changes were observed by $\mathrm{P} 4$ lesion in either type of mice (Fig. $5 E_{1}, F_{1}$ ).

This phenotypic change was quantified by measuring the area of A2-A3, B2-B3, C2-C3, D2-D3, or E2-E3 barrels. After lesion on $\mathrm{P} 0$ or $\mathrm{P} 2$, the ratio of the $\mathrm{C} 2-\mathrm{C} 3$ area relative to the total measured area was significantly greater in GLT1-KO mice than in control mice ( $p<0.01$ for each, Mann-Whitney $U$ test) (Fig. $6 C)$. No such difference was observed in mice lesioned on $\mathrm{P} 4$ $(p>0.05)$. Conversely, the ratio of the summed B2-B3 and D2-D3 areas relative to the total measured area was significantly lower in GLT1-KO mice than in control mice lesioned on P0 or P2 $(p<0.01$ for each), but not in mice lesioned on P4 $(p>0.05)$ (Fig. 6D). Consequently, the MPI, as obtained from $(\mathrm{B} 2+\mathrm{B} 3+$ $\mathrm{D} 2+\mathrm{D} 3) / 2(\mathrm{C} 2+\mathrm{C} 3)$, was significantly lower in GLT1-KO mice than in control mice lesioned on P0 or P2: $1.61 \pm 0.34(n=11$; mean $\pm \mathrm{SD})$ versus $3.80 \pm 2.21(n=8)$ by P0 lesion and $1.34 \pm$ $0.21(n=10)$ versus $2.79 \pm 1.79(n=10)$ by P2 lesion, respectively ( $p<0.01$ for each) (Fig. $6 E$ ). No significant differences in the MPI were observed in the cortex from mice lesioned on P4 $[0.99 \pm 0.05(n=9)$ vs $0.99 \pm 0.02(n=7) ; p>0.05]$ or in the intact cortex ( $p>0.05$ for each) (Fig. $6 E)$.

Therefore, lesion-induced plasticity was significantly reduced in GLT1-KO mice. Furthermore, normal temporal closing of the critical period (i.e., by $\mathrm{P} 4$ in both genotypes) was confirmed again by row $\mathrm{C}$ whisker lesion experiment.

Presynaptic and postsynaptic patterning of thalamocortical synapses

CO intensity reflects mitochondrial enzymatic activity in both presynaptic and postsynaptic elements (Wong-Riley and Welt, 1980). To visualize the patterning of presynaptic and postsynaptic elements, double fluorescent labeling was used: VGluT2 immunofluorescence for thalamocortical afferent terminals and Nissl staining for neuronal arrangement. In both types of mice, thalamocortical terminals were clearly clustered, but neuronal patterning was still somewhat obscure at P5 (data not shown). At P6, neuronal somata in the lamina IV clustered into the barrel septae, and surrounded thalamocortical terminal clusters in GLT1-KO and control mice (Fig. $3 I-L$ ). In mice subjected to ION transection on $\mathrm{P} 5$, presynaptic and postsynaptic patterns were maintained in the lesioned cortex of both genotypes (Fig. $4 I-L)$. These results confirm that both patterns are normal in terms of whiskerrelated patterning and critical period termination in GLT1-KO mice.

To clarify the origin of the reduced plasticity, mice whose row C whiskers were lesioned on P2 were subjected to double labeling for VGluT2 and metabotropic glutamate receptor mGluR5 (Fig. $5 G-J$ ) or Nissl staining (Fig. $5 K-N$ ). mGluR5 was used to examine dendritic patterning of cortical neurons, because it is exclusively expressed on dendrites and spines in adult rodents (Shigemoto et al., 1993; Lujan et al., 1996), and this was also true in the neonatal somatosensory cortex (supplemental Fig. S2, available at www.jneurosci.org as supplemental material). In the lesioned side of GLT1-KO and control mice, VGluT2 and mGluR5 immunofluorescences were detected in hollows of fused row $\mathrm{C}$ barrels in a spatially matched manner (Fig. 5G-J). Moreover, cortical neurons of row $\mathrm{C}$ barrels were arranged at the border with row $\mathrm{B}$ and row D barrels, and surrounded VGluT2-stained fused thalamocortical pattern (Fig. $5 K-N$ ). Again here, milder reduction of lesioned row $\mathrm{C}$ barrels was reproduced in GLT1-KO mice. Therefore, the reduced cortical plasticity in GLT1-KO mice involves presynaptic, neuronal, and dendritic elements in the lamina IV.

\section{Normal cortical cytoarchitecture, GLAST levels, and glutamate receptor levels in GLT1-KO neonates}

To seek possible reasons for altered plasticity, we compared the histology and expression of glutamatergic signaling molecules between GLT1-KO and control neonates (Fig. $7 A-N$ ). In P0 GLT1-KO mice, no apparent differences were discernable in the histoarchitecture of the somatosensory cortex, in which the laminas I, V, and VI, but not II-IV, were differentiated (Fig. 7A-D). Likewise, similar patterns and intensity were noted by immunohistochemistry for neurofilament, VGluT2, MAP2, and GLAST (Fig. 7E-L). At P2, GLAST was detected selectively in astrocytic elements in both GLT1-KO and control mice (Fig. $7 M, N$ ). By immunoblot using P2 cortical homogenates, comparable protein 
levels were observed for GLAST (100.0 \pm 4.2 and $111.1 \pm 16.7 \%$ in control and GLT1-KO; mean \pm SD), AMPA receptors as detected with a mixture of GluR1 and GluR2 antibodies (100.0 \pm 10.5 and $117.5 \pm 2.2 \%)$, the NMDA receptor NR1 subunit (100.0 \pm 10.4 and $114.4 \pm 18.2 \%)$, and mGluR5 $(100.0 \pm 4.9$ and $101.6 \pm$ 9.1\%) $(p>0.05$ and $n=3$ for each, Student's $t$ test) (Fig. 7O). Therefore, GLT1-KO neonates are normal in histoarchitectonic development of the somatosensory cortex and in cortical contents of GLAST and glutamate receptors. This is consistent with a previous study showing unchanged protein levels of GLAST and NMDA receptor NR2A/B subunits in the cortex of P10 GLT1-KO mice (VoutsinosPorche et al., 2003).

\section{Elevated extracellular glutamate level in the somatosensory cortex of GLT1-KO neonates}

Because glutamate transporters play a key role in keeping the extracellular glutamate concentration low, we used microdialysis to address whether the lack of GLT1 affects extracellular glutamate levels in the somatosensory cortex of P3 mice. The genotyping revealed that, of 18 mice examined, 5 were GLT1-KO mice, 8 were GLT1heterozygous mice, and 5 were control mice. Histological examinations confirmed that 0.5 -mm-long microdialysis membranes were located in the somatosensory cortex. An acute increase in extracellular glutamate levels was observed immediately after insertion of the probe regardless of the genotype; this is attributable to the efflux of intracellular glutamate mainly from neurons damaged by probe insertion. Extracellular glutamate levels decreased to stable low levels within $30 \mathrm{~min}$ of probe insertion. The average value of six samples collected consecutively from 30 to $60 \mathrm{~min}$ after probe insertion was calculated to evaluate extracellular glutamate levels in each animal. Extracellular glutamate levels in GLT1-KO mice $(n=5)$ were significantly higher than those in control mice $(n=5)(p=0.017$; one-way ANOVA; Scheffés post hoc test) (Fig. 7P). Extracellular glutamate values in GLT1-KO mice also tended to be higher than those in GLT1heterozygous mice $(n=8)$, but the difference was not statistically significant $(p=0.087$ ). The ablation of GLT1 thus leads to elevated extracellular glutamate level in the somatosensory cortex of GLT1-KO neonates.

Lesion-induced plasticity is also reduced in GLAST-KO mice If reduced glutamate uptake function is involved in reduced plasticity, the lack of GLAST could also cause the similar effect, although its expression and functional contribution in the cortex are lower than those by GLT1 (Lehre et al., 1995; Tanaka et al., 1997). To test this possibility, we lesioned row C whiskers of mutant mice lacking GLAST by giving electrocautery to row $\mathrm{C}$ follicles at $\mathrm{P} 2$ and $\mathrm{CO}$ histochemistry at $\mathrm{P} 15$. The reduction in the MPI in GLAST-KO mice $(1.30 \pm 0.22 ; n=9$; mean \pm SD) was significantly less than that in control littermates $(1.92 \pm 0.61 ; n=$ 12) (Figs. $6 F, 8 A, B)(p<0.01$, Mann-Whitney $U$ test $)$. No significant difference was observed in intact cortex $(0.96 \pm 0.02$ in GLAST-KO and $0.96 \pm 0.03$ in control; $p>0.05$ ). Therefore, critical period plasticity is reduced in GLAST-KO mice as well, favoring the notion that glutamate uptake function is important for lesion-induced plasticity.

\section{Discussion}

\section{Glutamate transporters selectively magnify} lesion-induced plasticity

GLT1-KO mice normally gained the body weight until P15. No apparent differences were noted in the histoarchitecture of the somatosensory cortex and in cortical contents of GLAST and glutamate receptors in GLT1-KO neonates. Furthermore, tem- 


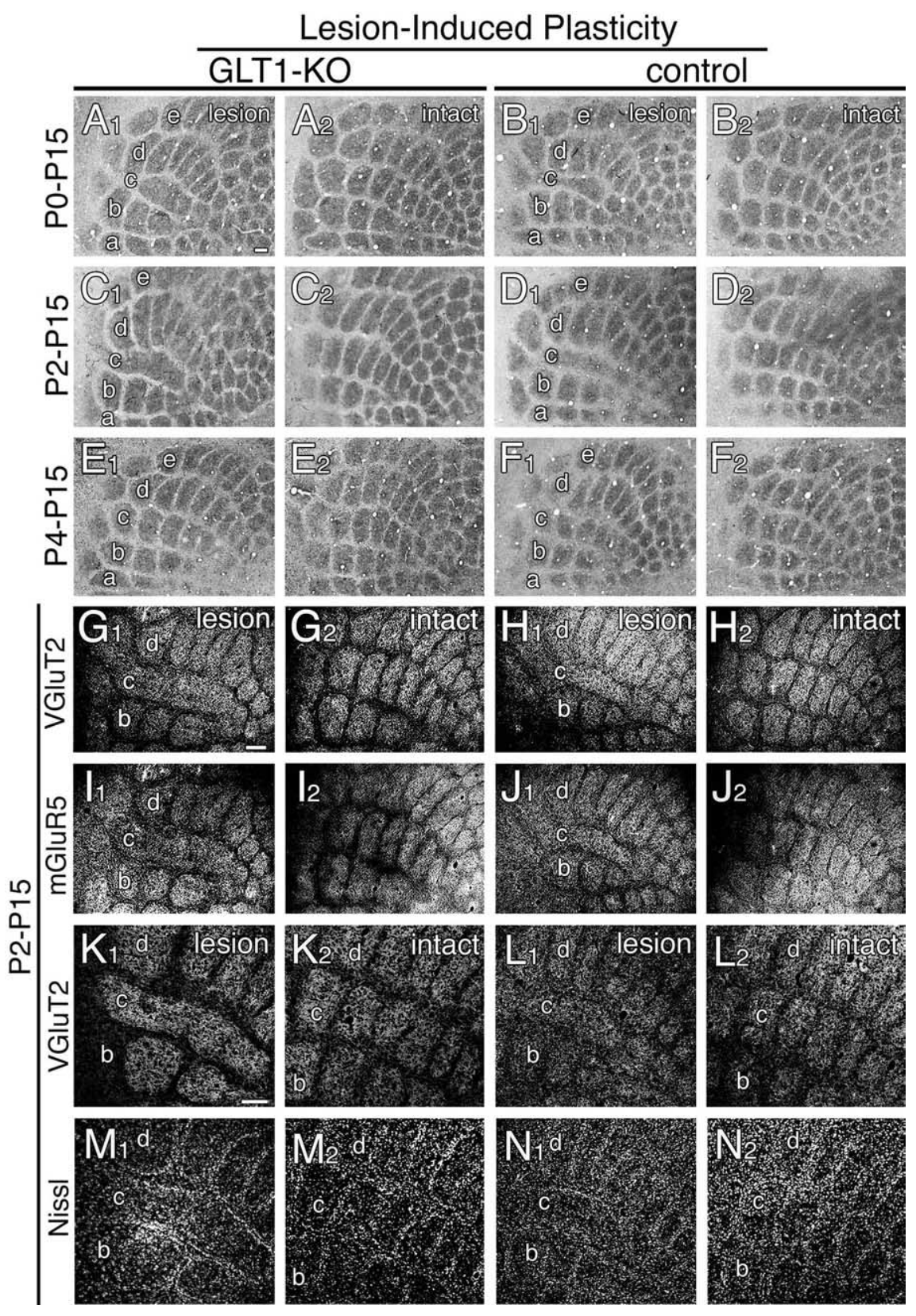

Figure 5. Row $C$ whisker lesion experiment showing diminished magnitude of lesion-induced plasticity in GLT1-KO mice. GLT1-KO $(\boldsymbol{A}, \boldsymbol{C}, \boldsymbol{E}, \boldsymbol{G}, \boldsymbol{I}, \boldsymbol{K}, \boldsymbol{M})$ and control $(\boldsymbol{B}, \boldsymbol{D}, \boldsymbol{F}, \boldsymbol{H}, \boldsymbol{J}, \boldsymbol{L}, \boldsymbol{N})$ mice. After electrocautery of row $($ whisker follicles at $\mathrm{PO}(\boldsymbol{A}, \boldsymbol{B}), \mathrm{P} 2(\boldsymbol{C}$, $\boldsymbol{D}, \boldsymbol{G}-\boldsymbol{N})$, or P4 $(\boldsymbol{E}, \boldsymbol{F})$, mice were killed at P15 for C0 histochemistry $(\boldsymbol{A}-\boldsymbol{F})$, VGluT2 immunofluorescence $(\boldsymbol{G}, \boldsymbol{H}, \boldsymbol{K}, \boldsymbol{L})$, mGluR5 immunofluorescence $(\boldsymbol{I}, \boldsymbol{J})$, and Niss staining $(\boldsymbol{M}, \boldsymbol{N})$. Letters a-e indicate five rows of cortical barrels. Scale bars, $100 \mu \mathrm{m}$.

development (Shibata et al., 1997) (Fig. 1) and that abundant GLT1 is provided to cortical astrocytes during the critical period, these transporters likely cooperate to magnify the lesion-induced plasticity in the somatosensory cortex. This molecular function will facilitate developmental remodeling of somatosensory maps in an activity-dependent manner.

\section{Glutamate transporters and receptors} play distinct roles in barrel development NMDA receptors and group I mGluRs (mGluR1 and mGluR5) mediate activitydependent $\mathrm{Ca}^{2+}$ influx and release, respectively, and trigger long-term potentiation and depression of synaptic transmission (Bliss and Collingridge, 1993; Aiba et al., 1994; Conquet et al., 1994; Bear, 1996). Both forms of synaptic plasticity can be readily elicited at thalamocortical synapses during the critical period, and are thought to regulate activity-dependent synaptic refinement (Crair and Malenka, 1995; Feldman et al., 1998; Barth and Malenka, 2001). Indeed, whisker-related patterning of thalamocortical synapses is impaired in mice defective for the NR1 (GluR $\zeta 1$ ) subunit of NMDA receptors, mGluR5, and its effector enzyme type- 1 phospholipase $C \beta$ (PLC $\beta 1$ ) (Li et al., 1994; Iwasato et al., 1997, 2000; Hannan et al., 2001). Of these, molecular ablation is proved specific to the postsynaptic (cortical) side of thalamocortical synapses in cortex-specific NR1-KO mice (Iwasato et al., 2000). This study has provided the evidence that cortical patterning is completely lost in the mutant mice despite the presence of thalamocortical patterning, although smaller in size and less sharply defined than control mice. Mutant mice lacking mGluR5 or PLC $\beta 1$, which are predominantly expressed in the cortex but very low in the thalamus (Testa et al., 1995; Watanabe et al., 1998) (supplemental Fig. S2, available at www.jneurosci.org as supplemental material), manifest similar phenotypes (Hannan et al., 2001). Considering that thalamocortical projections are pat-

poral profile of barrel development was normal in terms of barrel appearance and critical period termination. Thus, the reduced plasticity in GLT1-KO mice is unlikely to result from general defects in body growth or brain development. GLT1-KO mice are known to start dying suddenly from intractable seizures in the third postnatal week (Tanaka et al., 1997), raising the possibility that the epileptogenic properties could affect the plasticity. However, there is little, if any, possibility of this, because the plasticity is also reduced in GLAST-KO mice, a nonepileptogenic model that normally grows and survives (Watase et al., 1998). Moreover, comparable size of CO-stained C2-C3 barrels at P4 and P5 suggests that thalamocortical afferents subserving row $\mathrm{C}$ barrels maintain their ability to expand in both GLT1 and control mice. Taking that GLAST is highly expressed in astrocytes throughout terned earlier than postsynaptic neurons (Erzurumlu and Jhaveri, 1990; Schlaggar and O'Leary, 1994), signaling through these glutamate receptors translate patterned presynaptic activity into subsequent postsynaptic patterning, leading to the formation of whisker-related somatosensory maps.

Because glutamate transporters control glutamate receptormediated synaptic transmission and plasticity (Katagiri et al., 2001; Wadiche and Jahr, 2005; Takayasu et al., 2005, 2006), we had surmised before experiments that phenotypes of glutamate transporter-defective mice might approximate those in mutant mice lacking glutamate receptors. However, whisker-related patterns were formed normally, and presynaptic and postsynaptic patterns were normally differentiated in GLT1-KO mice. Instead, we found reduced lesion-induced plasticity in GLT1-KO and 
GLAST-KO mice, which contrasts with normal plasticity in cortex-specific NR1-KO (Iwasato et al., 2000; Datwani et al., 2002) and mGluR5-KO (Fig. 8C,D) mice. Thus, the different phenotypes have eventually highlighted their distinct roles in barrel development; glutamate receptors play an essential role in whisker-related topographical patterning of somatosensory synapses, whereas glutamate transporters facilitate their remodeling. Armed with both machineries, crude somatosensory maps can be normally refined and reorganized into functional ones during the critical period.

\section{GLT1 switching during critical period is a general phenomenon in somatosensory stations}

Predominant astrocytic expression of GLT1 in the adulthood (Chaudhry et al., 1995) is preceded by neuronal expression in the fetal and neonatal cerebellum and spinal cord (Furuta et al., 1997; Yamada et al., 1998; Northington et al., 1999). In the present study, we documented this in the somatosensory cortex, and have demonstrated that GLT1 switching proceeds during the critical period when synaptic circuits are highly plastic and sensitive to external stimuli. This prompted us to further examine GLT1 switching in subcortical relay nuclei. Switchover to predominant astrocytic expression was accomplished by P6 in the subnucleus interpolaris of the trigeminal spinal nucleus (SpI) (supplemental Fig. S3, available at www.jneurosci.org as supplemental material), P3 to P5 in the trigeminal principal sensory nucleus $(\mathrm{Pr})$ (supplemental Fig. S4, available at www. jneurosci.org as supplemental material), and P2 in the ventrobasal thalamus (VB) (supplemental Fig. S5, available at www. jneurosci.org as supplemental material). Intriguingly, these stages correspond to the stages when critical period is terminated at each somatosensory station of mice: P5-P8 in the Sp5I, P3 in the Pr, and P2-P3 in the VB (Woolsey et al., 1979; Durham and Woolsey, 1984; Chiaia et al., 1992; Toki et al., 1999). Therefore, neuron-to-astrocyte switching of GLT1 expression occurs around the critical period at each somatosensory station, suggesting its potential involvement in synaptic circuit development at the subcortical levels too.

\section{Postulated mechanisms of glutamate transporter-mediated lesion-induced plasticity}

How can glutamate transporters regulate lesion-induced plasticity? Four possible mechanisms are discussed below.

Astrocytic glutamate transporters play a major role in rapid and bulk uptake of extracellular glutamate (Takayasu et al., 2005), and this function is further facilitated by coexpression of glutamine synthetase that converts glutamate to glutamine (Erecinska and Silver, 1990). Despite normal expression of
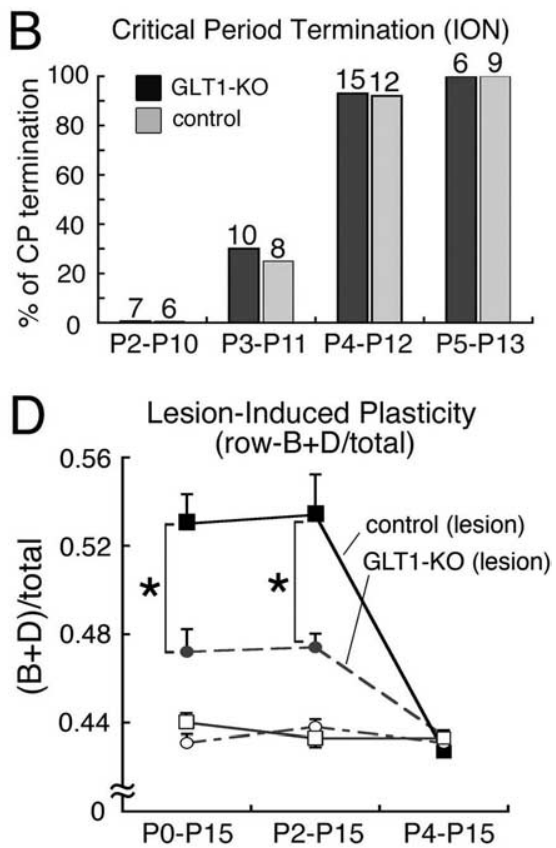

F Map Plasticity Index

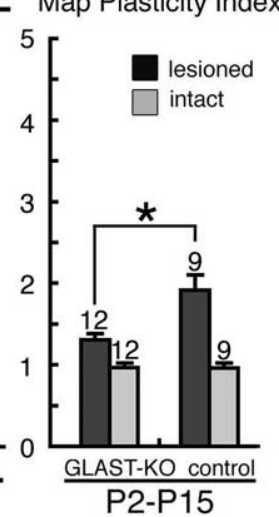

Map Plasticity Index

lesioned intact
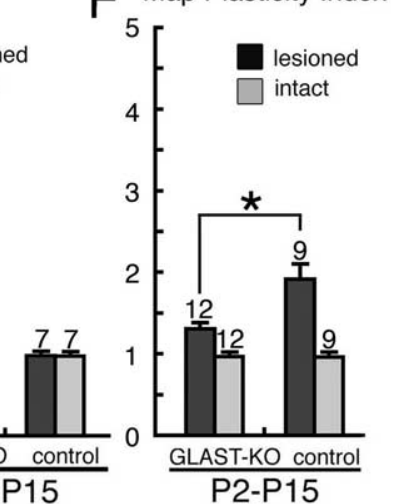

Figure 6. Quantitative comparisons in developmental appearance $(\boldsymbol{A})$, critical period termination $(\boldsymbol{B})$, and lesion-induced of mice in which the critical period is terminated $(B)$ increase with age in both GLT1-KO (black bars) and contro filled and open symbols indicate the lesioned or intact side, respectively. $\boldsymbol{F}_{1} \boldsymbol{F}$ The map plasticity index $[\mathrm{B} 2+\mathrm{B} 3+\mathrm{D} 2+$ $\left.C_{2}+(3)\right]$ in GLT1-KO $(\boldsymbol{E})$ and GLAST-KO $(\boldsymbol{F})$ mice and their littermate controls. The black bars and gray bars indicate the lesioned and intact side, respectively. Error bars represent SEM. The numbers on the bars indicate the total number of mice examined at each stage. ${ }^{*} p<0.01$.

GLAST, extracellular glutamate levels were significantly elevated in the somatosensory cortex of GLT1-KO neonates. Although cortical contents of glutamate receptors were not changed, the chronic elevation of ambient glutamate levels could affect presynaptic release function and postsynaptic activation. Indeed, blocking of glutamate transporters in immature neocortex and hippocampus generates recurrent NMDA receptor-mediated currents associated with synchronous $\mathrm{Ca}^{2+}$ oscillations in the entire neuronal population (Kidd and Isaac, 2000; Demarque et al., 2004; Cattani et al., 2007; Milh et al., 2007). Elevated glutamate levels could also affect synaptic competition so that inactive afferents can even activate postsynaptic targets substantially, as active afferents do. In this regard, the mechanisms that maximize such "activity discriminator" function should magnify lesioninduced plasticity, and factors that shift from the optimal point 

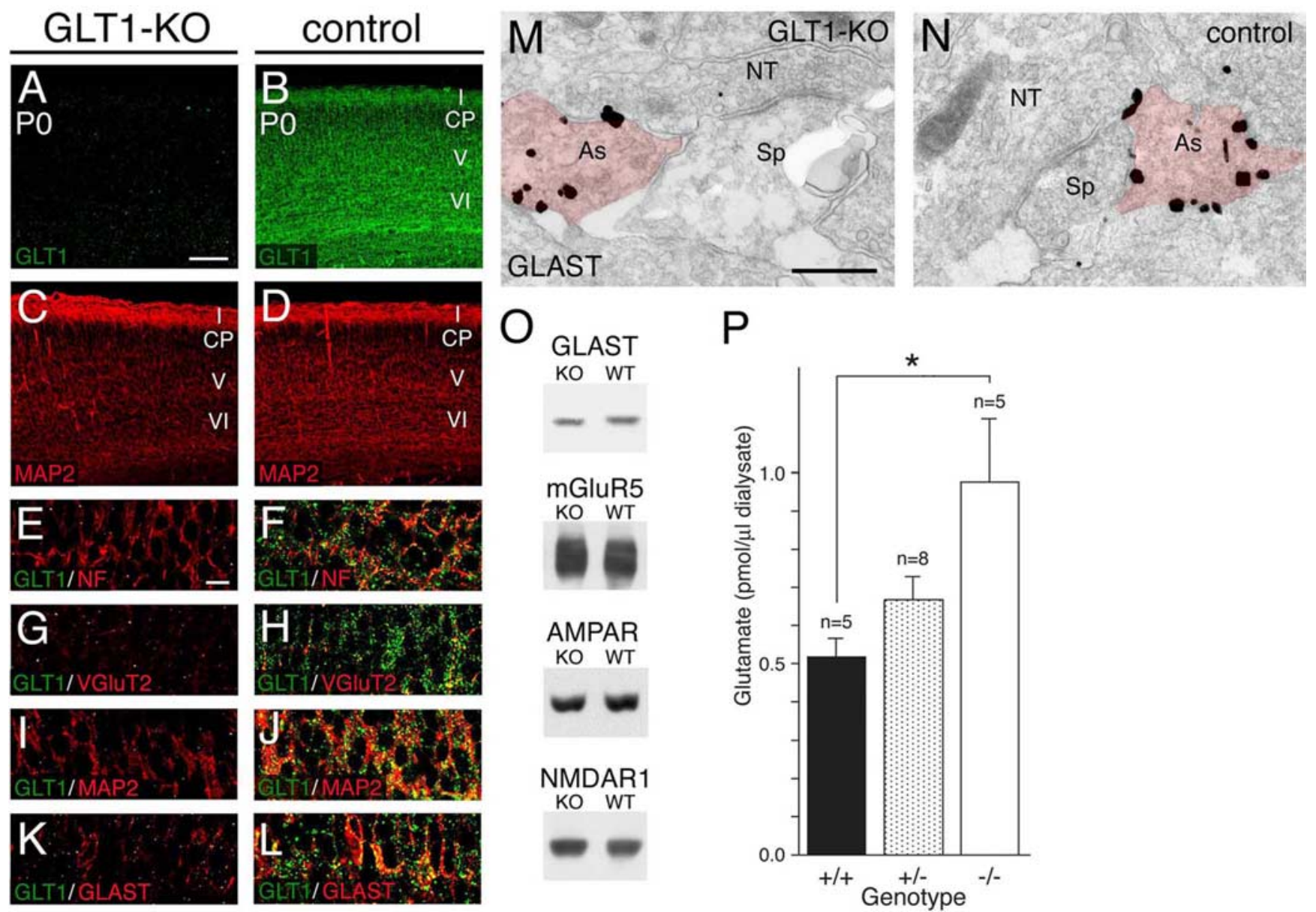

Figure 7. Elevated extracellular glutamate levels in the somatosensory cortex of GLT1-K0 mice. $\boldsymbol{A}-\boldsymbol{L}$, Normal histoarchitecture $(\boldsymbol{A}-\boldsymbol{D})$ and comparable expression of neuronal markers $(\boldsymbol{E}-\boldsymbol{L})$ in the somatosensory cortex of PO GLT1-KO $(\boldsymbol{A}, \boldsymbol{C}, \boldsymbol{E}, \boldsymbol{G}, \boldsymbol{I}, \boldsymbol{K})$ and control $(\boldsymbol{B}, \boldsymbol{D}, \boldsymbol{F}, \boldsymbol{H}, \boldsymbol{J}, \boldsymbol{L})$ mice. Low-power images of the somatosensory cortex stained for $G L T 1(A, B), M A P 2(C, D, I, J)$, neurofilaments $(\boldsymbol{E}, \boldsymbol{F})$, VGluT2 $(\boldsymbol{G}, \boldsymbol{H})$, and GLAST $(\boldsymbol{K}, \boldsymbol{L}) . \boldsymbol{M}, \boldsymbol{N}$, Preembedding silver-enhanced immunogold electron microscopy for GLAST at P2. Note selective distribution of GLAST on the cell membrane of astrocytes (As), but not in nerve terminals (NT) or dendritic spines (Sp), in GLT1-KO $(\boldsymbol{M})$ and control ( $\boldsymbol{N}$ ) neonates. $\mathbf{0}$, Immunoblots of cortical extracts from P2 mice show comparable protein levels for GLAST, mGluR5, AMPA receptor GluR1 and GluR2 subunits (AMPAR), and NMDA receptor NR1 subunit (NMDAR1) in GLT1-K0 and control mice. $\boldsymbol{P}$, Microdialysis in the somatosensory cortex of $\mathrm{P} 3$ control $(+/+; n=5$; filled bar), GLT1-heterozygous ( $+/-; n=8$; striped bar), and GLT1-KO $(-/-; n=5$; open bar) mice. Extracellular glutamate levels are significantly elevated in GLT1-KO mice compared with control mice. Error bars represent SEM, and the asterisk indicates statistical significance ( $p<0.05$; one-way ANOVA, Scheffé's post hoc test). Scale bars: (in $\boldsymbol{A}) \boldsymbol{A}-\boldsymbol{D}$, $100 \mu \mathrm{m}$; (in $E) E-L, 10 \mu \mathrm{m}$; (in $M) M, N, 500 \mathrm{~nm}$.

would blunt the plasticity. Apparent normal plasticity in cortexspecific NR1-KO and mGluR5-KO mice suggests that other molecular machineries, whose function is fueled by glutamate transporters, should fulfill this role. We hypothesize that non-NMDAtype glutamate receptors are the possible candidate, because Schlaggar et al. (1993) have demonstrated that lesion-induced cortical plasticity is diminished by pharmacological blockade with high concentrations of D-2-amino-5-phosphovaleric acid that sufficiently silence AMPA receptor-mediated cortical excitation as well as NMDA receptor-mediated one. Therefore, the first mechanism is that glutamate transporters regulate lesioninduced plasticity through modulation of non-NMDA receptor activation.

Lesion-induced plasticity is also reduced by depletion of cholinergic neurons (Bear and Singer, 1986; Zhu and Waite, 1998; Nishimura et al., 2002). Moreover, elevated extracellular serotonin levels impair branch elaboration and collateral retraction of thalamocortical afferents (Cases et al., 1996; Vitalis et al., 1998; Young-Davies et al., 2000; Rebsam et al., 2002), although the extracellular serotonin level per se is unlikely to affect the plasticity (Rebsam et al., 2005). Considering the facts that muscarinic acetylcholine receptors modulate synaptic plasticity at glutamatergic synapses (Anagnostaras et al., 2003; Shinoe et al., 2005) and that $5-\mathrm{HT}_{1 \mathrm{~B}}$ serotonin receptor on thalamocortical afferents strongly inhibits their synaptic transmission (Bennett-Clarke et al., 1993; Rhoades et al., 1994; Lotto et al., 1999; Laurent et al., 2002), functional interplay between glutamatergic and other signalings seems important for lesion-induced plasticity. Thus, the second mechanism is that their altered balance caused by glutamate transporter deficits might interfere with the plasticity.

When synaptic glutamate release is increased, obligatory $\mathrm{Na}^{+}$ influx coupled with glutamate transport enhances glucose utilization, glycolysis, and lactate release in astrocytes (Magistretti et al., 1999). This energy substrate is then supplied to nearby neurons and synapses to maintain their activity (Voutsinos-Porche et al., 2003). Thus, the third mechanism is activity-dependent metabolic support by glutamate transporters, which might allow astrocytes in active barrels to supply more energy substrate, and thereby promote the growth and expansion of active synaptic circuits.

In subcortical relay nuclei of the somatosensory system, ION lesion induces neuronal death during the critical period, whereas 


\section{GLAST-KO}
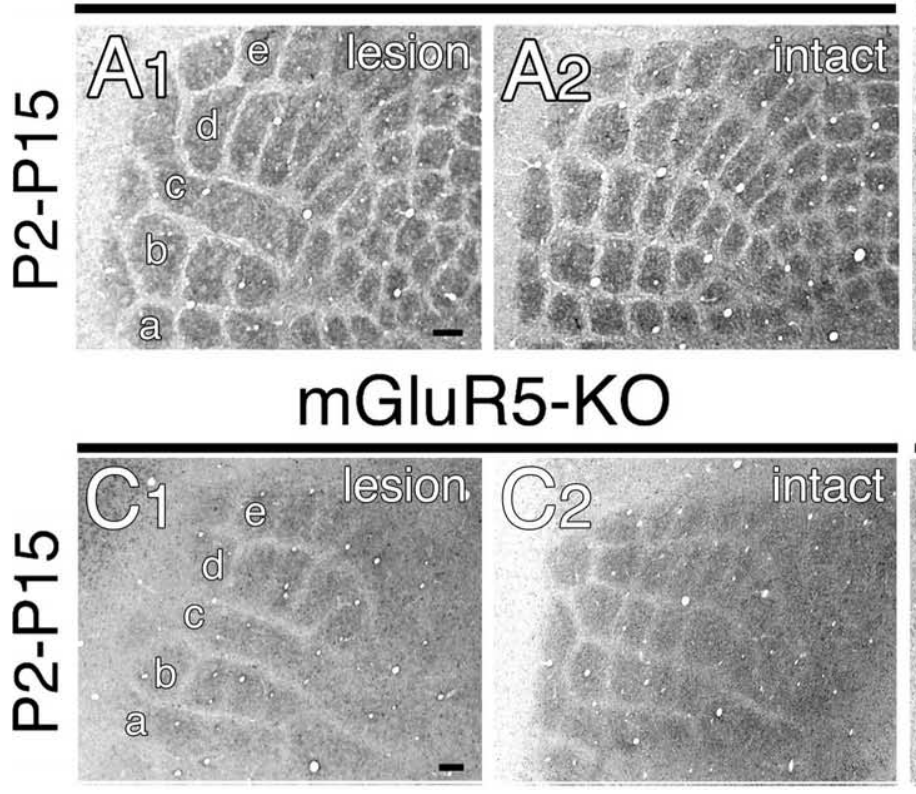

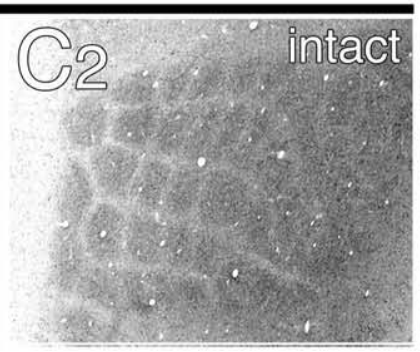

control

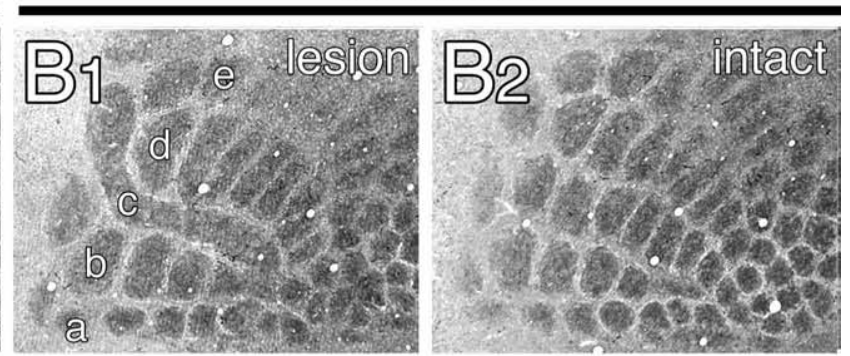

control

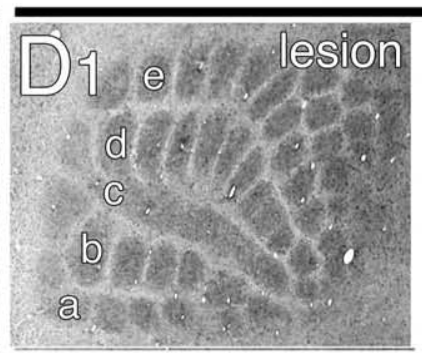

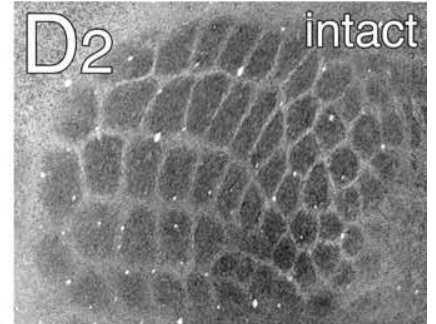

Figure 8. Lesion-induced plasticity is diminished in GLAST-K0 mice $(A, B)$, but normal in mGluR5-K0 mice $(\boldsymbol{C}, \boldsymbol{D})$. C $\mathrm{C}$ histochemistry was performed on P15 after row $\boldsymbol{C}$ whisker follicle cautery at P2 in $K 0(\boldsymbol{A}, \boldsymbol{C})$ and control $(\boldsymbol{B}, \boldsymbol{D})$ mice. In mGluR5-K0 and control mice, the map plasticity index in the lesioned [1.45 $\pm 0.04(n=6)$ vs $1.44 \pm 0.15(n=12)]$ and intact $[0.93 \pm 0.05(n=6)$ vs $0.97 \pm 0.05(n=12)]$ cortices did not differ significantly between mGluR5-K0 and control mice (Mann-Whitney $U$ test, $p>0.05$ for each). Note that C 0 patterns are slightly blurred in lesioned and intact cortices of mGluR5-K0 mice compared with control mice, likely because of impaired postsynaptic patterning in this mutant (Hannan et al., 2001). As to reduced map plasticity index in GLAST-K0 mice, see Figure 6 F. The lesioned cortex is shown on the left (e.g., $\left.\boldsymbol{A}_{7}\right)$ and the intact cortex is shown on the right $\left(\boldsymbol{A}_{2}\right)$ for each mouse. Letters a-e indicate five rows of cortical barrels. Scale bar, $100 \mu \mathrm{m}$.

neuronal loss is prevented by NMDA receptors and neurotrophins (Sugimoto et al., 1999; Baldi et al., 2000; de Rivero Vaccari et al., 2006). Considering that GLT1 is upregulated and switched to astrocytes in developing subcortical stations, the fourth mechanism is that elevate glutamate levels in GLT1-KO mice could reduce neuronal death in subcortical relay nuclei and thereby diminish lesion-induced plasticity in the somatosensory cortex. The role of subcortical relay nuclei has been also implied from normal occurrence of lesion-induced plasticity in the absence of barrel formation (Rebsam et al., 2005). These hypothetical mechanisms need to be tested in future studies.

In conclusion, glutamate transporters regulate lesion-induced plasticity in the developing somatosensory cortex by enhancing expansion of intact or active barrels and minimizing lesioned or inactive barrels in early postnatal life.

\section{References}

Agmon A, Yang LT, O’Dowd DK, Jones EG (1993) Organized growth of thalamocortical axons from the deep tier of terminations into layer IV of developing mouse barrel cortex. J Neurosci 13:5365-5382.

Aiba A, Kano M, Chen C, Stanton ME, Fox GD, Herrup K, Zwingman TA, Tonegawa S (1994) Deficient cerebellar long-term depression and impaired motor learning in mGluR1 mutant mice. Cell 79:377-388.

Anagnostaras SG, Murphy GG, Hamilton SE, Mitchell SL, Rahnama NP, Nathanson NM, Silva AJ (2003) Selective cognitive dysfunction in acetylcholine M1 muscarinic receptor mutant mice. Nat Neurosci 6:51-58.

Baldi A, Calia E, Ciampini A, Riccio M, Vetuschi A, Persico AM, Keller F (2000) Deafferentation-induced apoptosis of neurons in thalamic somatosensory nuclei of the newborn rat: critical period and rescue from cell death by peripherally applied neurotrophins. Eur J Neurosci 12:2281-2290.

Barth AL, Malenka RC (2001) NMDAR EPSC kinetics do not regulate the critical period for LTP at thalamocortical synapses. Nat Neurosci 4:235-236.
Bear MF (1996) A synaptic basis for memory storage in the cerebral cortex. Proc Natl Acad Sci USA 93:13453-13459.

Bear MF, Singer W (1986) Modulation of visual cortical plasticity by acetylcholine and noradrenaline. Nature 320:172-176.

Belford GR, Killackey HP (1980) The sensitive period in the development of the trigeminal system of the neonatal rat. J Comp Neurol 193:335-350.

Bennett-Clarke CA, Leslie MJ, Chiaia NL, Rhoades RW (1993) Serotonin 1B receptors in the developing somatosensory and visual cortices are located on thalamocortical axons. Proc Natl Acad Sci USA 90:153-157.

Berger UV, DeSilva TM, Chen W, Rosenberg PA (2005) Cellular and subcellular mRNA localization of glutamate transporter isoforms GLT1a and GLT1b in rat brain by in situ hybridization. J Comp Neurol 492:78-89.

Bliss TV, Collingridge GL (1993) A synaptic model of memory: long-term potentiation in the hippocampus. Nature 361:31-39.

Cases O, Vitalis T, Seif I, De Maeyer E, Sotelo C, Gaspar P (1996) Lack of barrels in the somatosensory cortex of monoamine oxidase A-deficient mice: role of a serotonin excess during the critical period. Neuron 16:297-307.

Cattani AA, Bonfardin VD, Represa A, Ben-Ari Y, Aniksztejn L (2007) Generation of slow network oscillations in the developing rat hippocampus after blockade of glutamate uptake. J Neurophysiol 98:2324-2336.

Chaudhry FA, Lehre KP, van Lookeren Campagne M, Ottersen OP, Danbolt NC, Storm-Mathisen J (1995) Glutamate transporters in glial plasma membranes: highly differentiated localizations revealed by quantitative ultrastructural immunocytochemistry. Neuron 15:711-720.

Chen W, Aoki C, Mahadomrongkul V, Gruber CE, Wang GJ, Blitzblau R, Irwin N, Rosenberg PA (2002) Expression of a variant form of the glutamate transporter GLT1 in neuronal cultures and in neurons and astrocytes in the rat brain. J Neurosci 22:2142-2152.

Chen W, Mahadomrongkul V, Berger UV, Bassan M, DeSilva T, Tanaka K, Irwin N, Aoki C, Rosenberg PA (2004) The glutamate transporter GLT1a is expressed in excitatory axon terminals of mature hippocampal neurons. J Neurosci 24:1136-1148.

Chiaia NL, Bennett-Clarke CA, Rhoades RW (1992) Differential effects of peripheral damage on vibrissa-related patterns in trigeminal nucleus 
principalis, subnucleus interpolaris, and subnucleus caudalis. Neuroscience 49:141-156.

Choi DW (1992) Excitotoxic cell death. J Neurobiol 23:1261-1276.

Conquet F, Bashir ZI, Davies CH, Daniel H, Ferraguti F, Bordi F, Franz-Bacon K, Reggiani A, Matarese V, Condé F, Collingridge GL, Crépel F (1994) Motor deficit and impairment of synaptic plasticity in mice lacking mGluR1. Nature 372:237-243.

Crair MC (1999) Neuronal activity during development: permissive or instructive? Curr Opin Neurobiol 9:88-93.

Crair MC, Malenka RC (1995) A critical period for long-term potentiation at thalamocortical synapses. Nature 375:325-328.

Danbolt NC (2001) Glutamate uptake. Prog Neurobiol 65:1-105.

Datwani A, Iwasato T, Itohara S, Erzurumlu RS (2002) Lesion-induced thalamocortical axonal plasticity in the S1 cortex is independent of NMDA receptor function in excitatory cortical neurons. J Neurosci 22:9171-9175.

Demarque M, Villeneuve N, Manent JB, Becq H, Represa A, Ben-Ari Y, Aniksztejn L (2004) Glutamate transporters prevent the generation of seizures in the developing rat neocortex. J Neurosci 24:3289-3294.

de Rivero Vaccari JC, Casey GP, Aleem S, Park WM, Corriveau RA (2006) NMDA receptors promote survival in somatosensory relay nuclei by inhibiting Bax-dependent developmental cell death. Proc Natl Acad Sci USA 103:16971-16976.

Durham D, Woolsey TA (1984) Effects of neonatal whisker lesions on mouse central trigeminal pathways. J Comp Neurol 223:424-447.

Erecinska M, Silver IA (1990) Metabolism and role of glutamate in mammalian brain. Prog Neurobiol 35:245-296.

Erzurumlu RS, Jhaveri S (1990) Thalamic axons confer a blueprint of the sensory periphery onto the developing rat somatosensory cortex. Dev Brain Res 56:229-234.

Feldman DE, Nicoll RA, Malenka RC, Isaac JT (1998) Long-term depression at thalamocortical synapses in developing rat somatosensory cortex. Neuron 21:347-357.

Finney DJ (1971) Probit analysis, Ed 3, p 333. Cambridge, UK: Cambridge UP.

Fox K, Schlaggar BL, Glazewski S, O’Leary DD (1996) Glutamate receptor blockade at cortical synapses disrupts development of thalamocortical and columnar organization in somatosensory cortex. Proc Natl Acad Sci USA 93:5584-5589.

Furuta A, Rothstein JD, Martin LJ (1997) Glutamate transporter protein subtypes are expressed differentially during rat CNS development. J Neurosci 17:8363-8375.

Hannan AJ, Blakemore C, Katsnelson A, Vitalis T, Huber KM, Bear M, Roder J, Kim D, Shin HS, Kind PC (2001) PLC- $\beta 1$, activated via mGluRs, mediates activity-dependent differentiation in cerebral cortex. Nat Neurosci 4:282-288.

Hertz L (1979) Functional interactions between neurons and astrocytes. I. Turnover and metabolism of putative amino acid transmitters. Prog Neurobiol 13:277-323.

Iwasato T, Erzurumlu RS, Huerta PT, Chen DF, Sasaoka T, Ulupinar E, Tonegawa S (1997) NMDA receptor-dependent refinement of somatotopic maps. Neuron 19:1201-1210.

Iwasato T, Datwani A, Wolf AM, Nishiyama H, Taguchi Y, Tonegawa S, Knopfel T, Erzurumlu RS, Itohara S (2000) Cortex-restricted disruption of NMDAR1 impairs neuronal patterns in the barrel cortex. Nature 406:726-731.

Jeanmonod D, Rice FL, Van der Loos H (1977) Mouse somatosensory cortex: development of the alterations in the barrel field which are caused by injury to the vibrissal follicles. Neurosci Lett 6:151-156.

Jeanmonod D, Rice FL, Van der Loos H (1981) Mouse somatosensory cortex: alterations in the barrelfield following receptor injury at different early postnatal ages. Neuroscience 6:1503-1535.

Katagiri H, Tanaka K, Manabe T (2001) Requirement of appropriate glutamate concentrations in the synaptic cleft for hippocampal LTP induction. Eur J Neurosci 14:547-553.

Kato T, Berger SJ, Carter JA, Lowry OH (1973) An enzymatic cycling method for nicotinamide-adenine dinucleotide with malic and alcohol dehydrogenases. Anal Biochem 53:86-97.

Kidd FL, Isaac JT (2000) Glutamate transport blockade has a differential effect on AMPA and NMDA receptor-mediated synaptic transmission in the developing barrel cortex. Neuropharmacology 39:725-732.

Killackey HP, Belford G, Ryugo R, Ryugo DK (1976) Anomalous organiza- tion of thalamocortical projections consequent to vibrissae removal in the newborn rat and mouse. Brain Res 104:309-315.

Kutsuwada T, Sakimura K, Manabe T, Takayama C, Katakura N, Kushiya E, Natsume R, Watanabe M, Inoue Y, Yagi T, Aizawa S, Arakawa M, Takahashi T, Nakamura Y, Mori H, Mishina M (1996) Impairment of suckling response, trigeminal neuronal pattern formation, and hippocampal LTD in NMDA receptor $\varepsilon 2$ subunit mutant mice. Neuron 16:333-344.

Laurent A, Goaillard JM, Cases O, Lebrand C, Gaspar P, Ropert N (2002) Activity-dependent presynaptic effect of serotonin $1 \mathrm{~B}$ receptors on the somatosensory thalamocortical transmission in neonatal mice. J Neurosci 22:886-900.

Lehre KP, Levy LM, Ottersen OP, Storm-Mathisen J, Danbolt NC (1995) Differential expression of two glial glutamate transporters in the rat brain: quantitative and immunocytochemical observations. J Neurosci 15:1835-1853.

Li Y, Erzurumlu RS, Chen C, Jhaveri S, Tonegawa S (1994) Whisker-related neuronal patterns fail to develop in the trigeminal brainstem nuclei of NMDAR1 knockout mice. Cell 76:427-437.

Lotto B, Upton L, Price DJ, Gaspar P (1999) Serotonin receptor activation enhances neurite outgrowth of thalamic neurones in rodents. Neurosci Lett 269:87-90.

Lujan R, Nusser Z, Roberts JD, Shigemoto R, Somogyi P (1996) Perisynaptic location of metabotropic glutamate receptors mGluR1 and mGluR5 on dendrites and dendritic spines in the rat hippocampus. Eur J Neurosci 8:1488-1500.

Magistretti PJ, Pellerin L, Rothman DL, Shulman RG (1999) Energy on demand. Science 283:496-497.

Matsugami TR, Tanemura K, Mieda M, Nakatomi R, Yamada K, Kondo T, Ogawa M, Obata K, Watanabe M, Hashikawa T, Tanaka K (2006) Indispensability of the glutamate transporters GLAST and GLT1 to brain development. Proc Natl Acad Sci USA 103:12161-12166.

Milh M, Becq H, Villeneuve N, Ben-Ari Y, Aniksztejn L (2007) Inhibition of glutamate transporters results in a "suppression-burst" pattern and partial seizures in the newborn rat. Epilepsia 48:169-174.

Mitani A, Tanaka K (2003) Functional changes of glial glutamate transporter GLT-1 during ischemia: an in vivo study in the hippocampal CA1 of normal mice and mutant mice lacking GLT-1. J Neurosci 23:7176-7182.

Miyazaki T, Fukaya M, Shimizu H, Watanabe M (2003) Subtype switching of vesicular glutamate transporters at parallel fibre-Purkinje cell synapses in developing mouse cerebellum. Eur J Neurosci 17:2563-2572.

Munger BL, Ide C (1988) The structure and function of cutaneous sensory receptors. Arch Histol Cytol 51:1-34.

Nishimura A, Hohmann CF, Johnston MV, Blue ME (2002) Neonatal electrolytic lesions of the basal forebrain stunt plasticity in mouse barrel field cortex. Int J Dev Neurosci 20:481-489.

Northington FJ, Traystman RJ, Koehler RC, Martin LJ (1999) GLT1, glial glutamate transporter, is transiently expressed in neurons and develops astrocyte specificity only after midgestation in the ovine fetal brain. J Neurobiol 39:515-526.

O’Leary DD, Ruff NL, Dyck RH (1994) Development, critical period plasticity, and adult reorganizations of mammalian somatosensory systems. Curr Opin Neurobiol 4:535-544.

Rauen T, Wiessner M, Sullivan R, Lee A, Pow DV (2004) A new GLT1 splice variant: cloning and immunolocalization of GLT1c in the mammalian retina and brain. Neurochem Int 45:1095-1106.

Rebsam A, Seif I, Gaspar P (2002) Refinement of thalamocortical arbors and emergence of barrel domains in the primary somatosensory cortex: a study of normal and monoamine oxidase a knock-out mice. J Neurosci 22:8541-8552.

Rebsam A, Seif I, Gaspar P (2005) Dissociating barrel development and lesion-induced plasticity in the mouse somatosensory cortex. J Neurosci 25:706-710.

Rhoades RW, Bennett-Clarke CA, Shi MY, Mooney RD (1994) Effects of 5 -HT on thalamocortical synaptic transmission in the developing rat. J Neurophysiol 72:2438-2450.

Schlaggar BL, O'Leary DD (1994) Early development of the somatotopic map and barrel patterning in rat somatosensory cortex. J Comp Neurol 346:80-96.

Schlaggar BL, Fox K, O’Leary DD (1993) Postsynaptic control of plasticity in developing somatosensory cortex. Nature 364:623-626.

Schmitt A, Asan E, Lesch KP, Kugler P (2002) A splice variant of glutamate 
transporter GLT1/EAAT2 expressed in neurons: cloning and localization in rat nervous system. Neuroscience 109:45-61.

Senft SL, Woolsey TA (1991) Growth of thalamic afferents into mouse barrel cortex. Cereb Cortex 1:308-335.

Shibata T, Yamada K, Watanabe M, Ikenaka K, Wada K, Tanaka K, Inoue Y (1997) Glutamate transporter GLAST is expressed in the radial gliaastrocyte lineage of developing mouse spinal cord. J Neurosci 17:9212-9219.

Shigemoto R, Nomura S, Ohishi H, Sugihara H, Nakanishi S, Mizuno N (1993) Immunohistochemical localization of a metabotropic glutamate receptor, mGluR5, in the rat brain. Neurosci Lett 163:53-57.

Shimuta M, Yoshikawa M, Fukaya M, Watanabe M, Takeshima H, Manabe T (2001) Postsynaptic modulation of ampa receptor-mediated synaptic responses and LTP by the type 3 ryanodine receptor. Mol Cell Neurosci 17:921-930

Shinoe T, Matsui M, Taketo MM, Manabe T (2005) Modulation of synaptic plasticity by physiological activation of $\mathrm{M}_{1}$ muscarinic acetylcholine receptors in the mouse hippocampus. J Neurosci 25:11194-11200.

Singer W (1995) Development and plasticity of cortical processing architectures. Science 270:758-764.

Sugimoto T, Xiao C, Takeyama A, He YF, Takano-Yamamoto T, Ichikawa H (1999) Apoptotic cascade of neurons in the subcortical sensory relay nuclei following the neonatal infraorbital nerve transection. Brain Res 824:284-290.

Takayasu Y, Iino M, Kakegawa W, Maeno H, Watase K, Wada K, Yanagihara D, Miyazaki T, Komine O, Watanabe M, Tanaka K, Ozawa S (2005) Differential roles of glial and neuronal glutamate transporters in Purkinje cell synapses. J Neurosci 25:8788-8793.

Takayasu Y, Iino M, Shimamoto K, Tanaka K, Ozawa S (2006) Glial glutamate transporters maintain one-to-one relationship at the climbing fiber-Purkinje cell synapse by preventing glutamate spillover. J Neurosci 26:6563-6572.

Tanaka K, Watase K, Manabe T, Yamada K, Watanabe M, Takahashi K, Iwama H, Nishikawa T, Ichihara N, Kikuchi T, Okuyama S, Kawashima N, Hori S, Takimoto M, Wada K (1997) Epilepsy and exacerbation of brain injury in mice lacking the glutamate transporter GLT-1. Science 276:1699-1702.

Testa CM, Standaert DG, Landwehrmeyer GB, Penney Jr JB, Young AB (1995) Differential expression of mGluR5 metabotropic glutamate receptor mRNA by rat striatal neurons. J Comp Neurol 354:241-252.

Toki S, Watanabe M, Ichikawa R, Shirakawa T, Oguchi H, Inoue Y (1999) Early establishment of lesion-insensitive mature barrelettes corresponding to upper lip vibrissae in developing mice. Neurosci Res 33:9-15.

Uchigashima M, Narushima M, Fukaya M, Katona I, Kano M, Watanabe M (2007) Subcellular arrangement of molecules for 2-arachidonoylglycerol-mediated retrograde signaling and its physiological contribution to synaptic modulation in the striatum. J Neurosci 227:3663-3676.

Van der Loos H, Woolsey TA (1973) Somatosensory cortex: structural alterations following early injury to sense organs. Science 179:395-398.

Vitalis T, Cases O, Callebert J, Launay JM, Price DJ, Seif I, Gaspar P (1998)
Effects of monoamine oxidase A inhibition on barrel formation in the mouse somatosensory cortex: determination of a sensitive developmental period. J Comp Neurol 393:169-184.

Voutsinos-Porche B, Bonvento G, Tanaka K, Steiner P, Welker E, Chatton JY, Magistretti PJ, Pellerin L (2003) Glial glutamate transporters mediate a functional metabolic crosstalk between neurons and astrocytes in the mouse developing cortex. Neuron 37:275-286.

Wadiche JI, Jahr CE (2005) Patterned expression of Purkinje cell glutamate transporters controls synaptic plasticity. Nat Neurosci 8:1329-1334.

Watanabe M, Nakamura M, Sato K, Kano M, Simon MI, Inoue Y (1998) Patterns of expression for the mRNA corresponding to the four isoforms of phospholipase C $\beta$ in mouse brain. Eur J Neurosci 10:2016-2025.

Watase K, Hashimoto K, Kano M, Yamada K, Watanabe M, Inoue Y, Okuyama S, Sakagawa T, Ogawa S, Kawashima N, Hori S, Takimoto M, Wada K, Tanaka K (1998) Motor discoordination and increased susceptibility to cerebellar injury in GLAST mutant mice. Eur J Neurosci 10:976-988.

Weller WL, Johnson JI (1975) Barrels in cerebral cortex altered by receptor disruption in newborn, but not in five-day-old mice (Cricetidoe and Muridae). Brain Res 83:504-508.

Wong-Riley M (1979) Changes in the visual system of monocularly sutured or enucleated cats demonstrable with cytochrome oxidase histochemistry. Brain Res 171:11-28.

Wong-Riley MT, Welt C (1980) Histochemical changes in cytochrome oxidase of cortical barrels after vibrissal removal in neonatal and adult mice. Proc Natl Acad Sci USA 77:2333-2337.

Woolsey TA, Van der Loos H (1970) The structural organization of layer IV in the somatosensory region (SI) of mouse cerebral cortex. The description of a cortical field composed of discrete cytoarchitectonic units. Brain Res 17:205-242.

Woolsey TA, Wann JR (1976) Areal changes in mouse cortical barrels following vibrissal damage at different postnatal ages. J Comp Neurol 170:53-66.

Woolsey TA, Anderson JR, Wann JR, Stanfield BB (1979) Effects of early vibrissae damage on neurons in the ventrobasal (VB) thalamus of the mouse. J Comp Neurol 184:363-380.

Yamada K, Watanabe M, Shibata T, Nagashima M, Tanaka K, Inoue Y (1998) Glutamate transporter GLT-1 is transiently localized on growing axons of the mouse spinal cord before establishing astrocytic expression. J Neurosci 18:5706-5713.

Yamakado M (1995) Remodelling in the array of cell aggregates in somatotopic representation of the facial vibrissae through the trigeminal sensory system of the mouse. Neurosci Res 23:399-413.

Young-Davies CL, Bennett-Clarke CA, Lane RD, Rhoades RW (2000) Selective facilitation of the serotonin(1B) receptor causes disorganization of thalamic afferents and barrels in somatosensory cortex of rat. J Comp Neurol 425:130-138.

Zhu XO, Waite PM (1998) Cholinergic depletion reduces plasticity of barrel field cortex. Cereb Cortex 8:63-72. 